\title{
Some Effects of Phosphate and Volatile Fatty Acid Salts on the Growth of Rumen Bacteria
}

\author{
By C. S. STEWART \\ Department of Microbiology, Rowett Research Institute, Aberdeen AB2 9 SB
}

(Received I3 February 1975; revised I5 March 1975)

SUMMARY

Bacterial cultures in media with a low $(0.38 \%, \mathrm{w} / \mathrm{v})$ initial glucose concentration showed much smaller $\mathrm{pH}$ changes during growth than cultures grown in media with excess $(\mathrm{I} \cdot 25 \%, \mathrm{w} / \mathrm{v})$ glucose. Increasing the concentration of the phosphate or volatile fatty acid salt (VFA salt, i.e. acetate, propionate or butyrate) in the media had no beneficial effect on cultures of Streptococcus bovis or Lactobacillus plantarum which had only minor falls in $\mathrm{pH}$ during growth (final $\mathrm{pH} \geqslant 6 \cdot 0$ ), but increased the dry weight yield (but not the molar growth yield) of cultures which had major $\mathrm{pH}$ falls (final $\mathrm{pH} \leqslant 4.6$ ) during growth. The improvements in dry weight yield could be correlated with increases in the pH buffering capacity of media caused by the increased phosphate or VFA salt concentration.

The response of Bacteroides ruminicola to increases in the phosphate concentration of media was qualitatively similar to that of $S$. bovis. However, VFA salts (particularly acetate) always decreased both dry weight and molar growth yield. The effects of VFA salts on three other rumen bacteria, Butyrivibrio fibrisolvens, Megasphaera elsdenii and Veillonella alcalescens, were varied. The possible mechanisms and ecological implications of the effects of these compounds are discussed.

\section{INTRODUCTION}

The complex nature of the nutrient requirements of rumen bacteria makes the formulation of fully defined media laborious and costly. A number of workers, therefore, have developed semi-defined media, containing protein hydrolysates and yeast extract but lacking centrifuged rumen fluid, for the study of the metabolism of rumen bacteria (Hobson, 1969).

Although an accurate comparison of the composition of media and of rumen fluid is hindered by the variable nature of rumen fluid, some semi-defined media contain only small amounts of the phosphates and volatile fatty acid (VFA) salts which are important in determining the $\mathrm{pH}$ buffering capacity of rumen fluid (Turner \& Hodgetts, 1955). The effect of $\mathrm{pH}$ control in increasing the yields of bacteria has been described (see, for example, Kempe, Halvorson \& Piret, 1950 and Sargeant, 1968), but apart from effects on pH, both classes of compound have other effects on micro-organisms. Phosphates are essential in small quantities, but may be toxic in high concentration (Good et al. 1966), whilst VFA salts have both inhibitory (Meynell, 1963; Hentges, 1967) and stimulatory (Bryant \& Robinson, 1962; Roche et al. 1973) effects on different micro-organisms under various conditions. Individual VFA may also have either inhibitory or stimulatory effects on the same bacteria, according to the concentrations of acid used (Hobson, Mann \& Smith, 1963).

The phosphate concentration of the semi-defined media reviewed by Hobson (1969) is around $6 \mathrm{mM}$, whereas according to Garton (I95I) comparable values for rumen fluid lie between 10 and $55 \mathrm{~mm}$. Similarly, VFA are present only as trace quantities in many semidefined media, whereas the VFA concentration of rumen fluid may be between 30 and $200 \mathrm{mM}$, and is commonly 90 to I IO mM (Hungate, I966). 
Table I. Concentrations of phosphate $\left(\mathrm{K}^{+}\right)$and $V F A\left(\mathrm{Na}^{+}\right)$salts in media

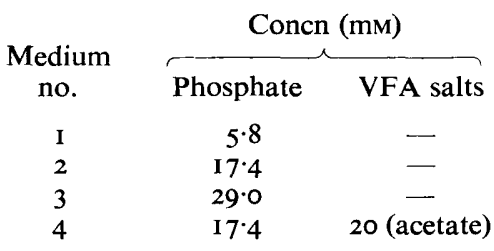

Medium
no.
5
6
7
8

\begin{tabular}{cl} 
Phosphate & \multicolumn{1}{c}{ Concn (mM) } \\
VFA salts \\
$17 \cdot 4$ & 50 (acetate) \\
$17 \cdot 4$ & 20 (propionate) \\
$17 \cdot 4$ & 20 (butyrate) \\
$17 \cdot 4$ & $\begin{array}{l}90 \text { (50 acetate }+20 \text { pro- } \\
\text { pionate }+20 \text { butyrate) }\end{array}$
\end{tabular}

The aim of the present study was to investigate the response of some rumen bacteria, grown in batch culture on semi-defined media, to increases in the phosphate and VFA salt concentrations of the media to levels within the rumen range. A preliminary study (Stewart, 1972) showed that only small effects were involved, but the results seemed likely to be relevant to a number of areas of current microbiological interest. For instance, the isolates used in the present study have been inoculated into the rumens of gnotobiotic lambs (Lysons et al. 197I ; Mann \& Stewart, 1974) as part of a continuing investigation into factors affecting the growth of rumen bacteria in vivo. It was therefore possible to compare the growth of these bacteria in the present study with that in the in vivo studies mentioned above.

\section{METHODS}

Bacteria. The bacteria were isolated by S. O. Mann and C. Grant at the Rowett Institute. The strains used were Streptococcus bovis S26; Lactobacillus plantarum LBI7; Bacteroides ruminicola 46/5(2); Butyrivibrio fibrisolvens 8834; Megasphaera (Peptostreptococcus) elsdenii LCI, and Veillonella alcalescens 692/I. Stock cultures were maintained on Mann's medium (No. 2 in the list of Hobson, 1969).

Media. Various amounts of phosphate (K+ salts) and VFA $\left(\mathrm{Na}^{+}\right.$salts) (media $\mathrm{I}$ to 8 , Table I), were added to a basal medium containing (g/roo ml): Bacto Casitone (Difco), $\mathrm{I} \cdot 0$; yeast extract (Difco), 0.25; cysteine- $\mathrm{HCl}, 0.05 ; \mathrm{NaHCO}_{3}, 0.4 ;\left(\mathrm{NH}_{4}\right)_{2} \mathrm{SO}_{4}, 0.09 ; \mathrm{NaCl}$, $0.09 ; \mathrm{MgSO}_{4}, 0.009 ; \mathrm{CaCl}_{2}, 0.009$; resazurin, $0.00 \mathrm{I}$; distilled water to $\mathrm{I} 00 \mathrm{ml}$. The $\mathrm{NaHCO}_{3}$, and the $\mathrm{CO}_{2}$ gas phase (see below) form part of the normal buffering system in these media. Two sets of media were prepared, containing 0.38 and $\mathrm{I} \cdot 25 \%(\mathrm{w} / \mathrm{v}) \mathrm{D}$-glucose, respectively. Most semi-defined media used for growing rumen bacteria contain $5.8 \mathrm{~mm}$-phosphate (Hobson, 1969). This was adopted as the basal level in the present study. Phosphate at I7.4 $\mathrm{mM}$ (as an equal-weight mixture of $\mathrm{KH}_{2} \mathrm{PO}_{4}$ and $\mathrm{K}_{2} \mathrm{HPO}_{4}$ ) was representative of many values in the literature for rumen phosphate concentration, and was used in the study of the effect of VFA salts. The proportions of VFA in the 90 mM-VFA mixture (medium 8) approximated to those found in the rumen, and the components of this mixture were studied separately (media 5, 6 and 7). The study of the effects of 20 mM-acetate (medium 4) allowed direct comparison between the effects of acetate and the other acids.

A solution of the Casitone, yeast extract, minerals and resazurin was sterilized by autoclaving at $12 \mathrm{I}{ }^{\circ} \mathrm{C}$ for $\mathrm{I} 5 \mathrm{~min}$. A solution of the other medium components was sterilized by filtration through Millipore membrane filters $(0.45 \mu \mathrm{m}$ pore size) and added to the autoclaved solution. Preparation and inoculation of media were done under oxygen-free $\mathrm{CO}_{2}$ (Hungate, 1950). Media were dispensed in Io $\mathrm{ml}$ amounts into $150 \times 16 \mathrm{~mm}$ test tubes which were then closed with rubber stoppers. The initial $\mathrm{pH}$ of each medium was $6 \cdot 70 \pm 0 \cdot 05$. The inoculum was $0 \cdot \mathrm{I} \mathrm{ml}$ of a $24 \mathrm{~h}$ culture on medium $\mathrm{I}$, containing $\mathrm{I} \cdot 25 \%(\mathrm{w} / \mathrm{v})$ glucose. 
Experiments at constant $\mathrm{pH}$. Batch cultures were set up under anaerobic conditions in vessels similar to the culture vessel described by Hobson (I965a), with provision for inoculation, $\mathrm{CO}_{2}$ bubbling and continuous $\mathrm{pH}$ measurement; the addition of $2 \mathrm{M}-\mathrm{NaOH}$ was controlled by the manual operation of a stopcock. The flasks (working volume $\mathrm{I} 20 \mathrm{ml}$ ) were inoculated with $\mathrm{IO} \mathrm{ml}$ of a $24 \mathrm{~h}$ culture on medium I, containing $\mathrm{I} \cdot 25 \%(\mathrm{w} / \mathrm{v})$ glucose. The introduction of this acidic inoculum, together with the continuous bubbling with $\mathrm{CO}_{2}$ (for stirring, and to maintain anaerobiosis) resulted in a fairly low $\mathrm{pH}(6 \cdot 3$ to $6 \cdot 4)$ before inoculation. During growth, cultures were maintained at $\mathrm{pH} 6 \cdot 3 \pm 0 \cdot \mathrm{I}$.

Analyses and chemicals. The buffer capacities of media and of rumen fluid were estimated by rapid titration of $50 \mathrm{ml}$ portions against $\mathrm{I} \mathrm{M}-\mathrm{HCl}$ using a Radiometer TI I titrator and model 26 pH meter (Radiometer, Copenhagen, Denmark). Rumen samples were from cannulated animals and were strained through light surgical gauze before filtration.

Dry weights of bacteria were estimated as described by Hobson (1965 $b$ ) from the turbidity of cultures (measured in an EEL colorimeter with a $640 \mathrm{~nm}$ filter; Evans Electroselenium Ltd, Harlow, Essex) after the construction of calibration curves using media I, 3 and 8. The relationship between turbidity and dry weight did not vary significantly between these media.

Cultures were harvested after $16 \mathrm{~h}$ incubation, which for all but $S$. bovis corresponded to the beginning of the stationary phase. Streptococcus bovis cultures showed maximum growth within about $\mathrm{I} 0 \mathrm{~h}$, and so were in the stationary phase for up to $6 \mathrm{~h}$ before harvesting. There was, however, no evidence of significant lysis of $S$. bovis or any of the other bacteria when incubated for up to $24 \mathrm{~h}$, nor was there evidence of uptake of glucose during the period after cessation of growth.

Cultures were centrifuged at $2{ }^{\circ} \mathrm{C}$ in a $\mathrm{L}_{2-50}$ preparative ultracentrifuge (Beckman Instruments, Glenrothes, Fife) at $100000 \mathrm{~g}$ for $60 \mathrm{~min}$. Then chemical analyses were made on the supernatants as follows: glucose by the glucose-oxidase method of Morley, Dawson \& Marks (1968); lactate and alcohol by the methods of Conway (1957); formate by the method of Barker \& Somers (I966); succinate by the method of Clark \& Porteous (I964); $C_{2}$ to $C_{4}$ VFA by the g.l.c. method of Whitelaw et al. (1970). The total phosphorus content of the bacteria was estimated by the method of Roach (I966), by using an acidified extract prepared as follows: about $50 \mathrm{mg}$ bacteria, which had been centrifuged at $3500 \mathrm{~g}$ for $20 \mathrm{~min}$, washed twice in distilled water and dried for $16 \mathrm{~h}$ at $105{ }^{\circ} \mathrm{C}$, were boiled for about 30 min in a mixture of $0.5 \mathrm{ml} \mathrm{H}_{2} \mathrm{SO}_{4}, 2 \mathrm{ml} \mathrm{HNO}_{3}$ and $\mathrm{I} \mathrm{ml} \mathrm{HClO}_{4}$ (all BDH Aristar grade) for about $30 \mathrm{~min}$.

Unless otherwise stated chemicals were $\mathrm{BDH}$ Analar grade except for $\mathrm{K}_{2} \mathrm{HPO}_{4}$ which was laboratory grade.

\section{RESULTS}

The changes in $\mathrm{pH}$ on addition of $\mathrm{HCl}$ to the eight types of media studied are shown in Fig. I. Since the three media containing 20 mM-VFA salt (media 4, 6 and 7 ) had almost identical buffer capacities, only medium 4, 20 mm-acetate, is shown in Fig. 4. Medium 8, with 17.4 mM-phosphate and $90 \mathrm{~mm}$-VFA, had a buffer capacity similar to a selection of 17 rumen fluid samples taken from five different sheep on various feeds. Medium 8 required the addition of $8 \mathrm{mmol} \mathrm{HCl} / \mathrm{IOO} \mathrm{ml}$ to lower the $\mathrm{pH}$ from 6.7 to 4.7 , while the rumen fluids required from $7 \cdot \mathrm{I}$ to $10 \mathrm{mmol}$. The glucose concentrations of the media had no effect on buffering capacity.

The concentrations of glucose used were chosen so that the lower $(0.38 \%$, w/v) would provide glucose-limited cultures, and the higher $(\mathrm{I} \cdot 25 \%, \mathrm{w} / \mathrm{v})$ provide cultures with excess glucose. None of the bacteria showed detectable growth in the basal medium without glucose. 


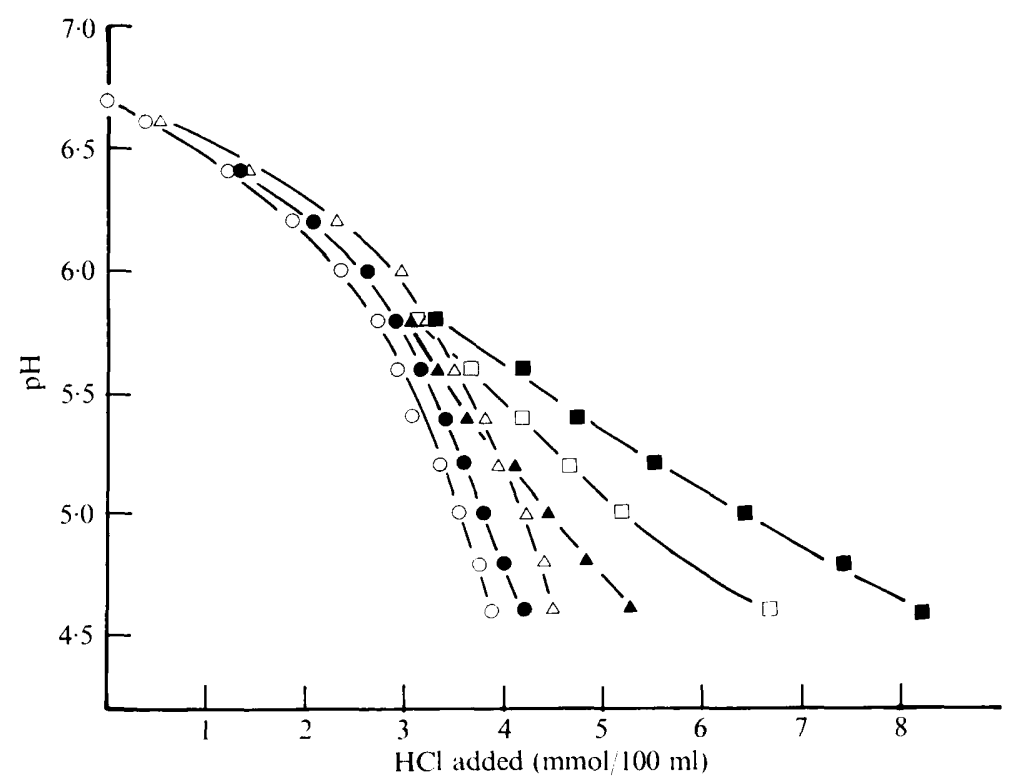

Fig. I. pH changes on addition of $\mathrm{HCl}$ to nutrient media. $\mathrm{O}, \boldsymbol{\ominus}, \Delta, \mathbf{\Delta}, \square, \boldsymbol{\square}$, Media I, 2, 3, 4, 5 and 8 , respectively. Media 6 and 7 gave results almost identical to those of medium 4 .

Streptococcus bovis, L. plantarum and Bact. ruminicola utilized all the $0.38 \%(\mathrm{w} / \mathrm{v})$ glucose during growth. With $\mathrm{Bu}$. fibrisolvens, however, about half of the $0.38 \%(\mathrm{w} / \mathrm{v})$ glucose remained after growth in media without VFA salts. Only when propionate was present was all of the glucose used. When the glucose concentration of the medium with propionate was increased above $0.38 \%(\mathrm{w} / \mathrm{v})$ no increase in growth of $\mathrm{Bu}$. fibrisolvens was observed.

The effects of the various phosphate concentrations and of the $90 \mathrm{~mm}-\mathrm{VFA}$ salt mixtures on the dry weight yields, molar growth yields (calculated from the amount of glucose apparently utilized during growth) and final $\mathrm{pH}$ of the bacterial cultures are shown in Table 2. In representative media (I, 3 and 8 ) with 0.38 and $\mathrm{I} \cdot 25 \%$ (w/v) glucose, S. bovis and L. plantarum gave average carbon recoveries of around $93 \%$, Bact. ruminicola around $80 \%$ and Bu. fibrisolvens around $75 \%$. Differences in carbon recoveries for any one bacterium in different media were small.

Table 2 shows that increasing the phosphate concentration of the medium generally lowered the molar growth yield. In media with excess glucose this was combined with increases in the dry weight yield. Control experiments using media containing $\mathrm{K}^{+}$as $\mathrm{KCl}$, showed that the range of $\mathrm{K}^{+}$concentrations in these media had no significant effect on any of the bacteria. In media with 5.8 and $29 \mathrm{~mm}$-phosphate the phosphorus levels in the bacteria ( $\mu \mathrm{g} / \mathrm{mg}$ dried bacteria) were 20 and $2 \mathrm{I}$ (S. bovis), 27 and 28 (L. plantarum), and 22 and 28 (Bact. ruminicola), respectively.

The bacteria showed more individual patterns of response to VFA salts than to phosphate. Thus whilst $S$. bovis and $L$. plantarum showed a similar response to all three acids, Bact. ruminicola seemed to be more adversely affected by acetate than by the other acids and in the media with excess glucose $50 \mathrm{~mm}$-acetate gave a depression of the molar growth yield equal to $76 \%$ of the effect of the 90 mM-VFA mixture (of which acetate comprised about $55 \%$ ). Propionate (20 mM) was as effective in stimulating growth of Bu. fibrisolvens as was the $90 \mathrm{~mm}$ mixture, and both acetate and butyrate slightly stimulated growth. Control 
Table 2. Effects of phosphate and VFA salts on the growth of S. bovis, L. plantarum and Bact. ruminicola, and of VFA salts on Bu. fibrisolvens

\begin{tabular}{|c|c|c|c|c|c|c|c|c|}
\hline \multicolumn{9}{|c|}{ Cultures were incubated for $\mathrm{I} 6 \mathrm{~h}$ at $38^{\circ} \mathrm{C}$. } \\
\hline & \multicolumn{2}{|c|}{ Addition (mM) } & \multicolumn{3}{|c|}{$0.38 \%(w / v)$ glucose } & \multicolumn{3}{|c|}{$\mathrm{I} \cdot 25 \%(\mathrm{~W} / \mathrm{v})$ glucose } \\
\hline Bacterium & $\begin{array}{l}\text { Phos- } \\
\text { phate }\end{array}$ & $\begin{array}{c}\text { VFA } \\
\text { salt }\end{array}$ & $\begin{array}{l}\text { Dry wt } \\
(\mathrm{mg} / \mathrm{ml})\end{array}$ & $Y_{\mathrm{glc}} *$ & $\begin{array}{c}\text { Final } \\
\mathrm{pH}\end{array}$ & $\begin{array}{l}\text { Dry wt } \\
(\mathrm{mg} / \mathrm{ml})\end{array}$ & $Y_{\mathrm{glc}}{ }^{*}$ & $\begin{array}{c}\text { Final } \\
\mathrm{pH}\end{array}$ \\
\hline S. bovis & $\begin{array}{r}5.8 \\
17 \cdot 4 \\
29 \cdot 0 \\
17.4\end{array}$ & $90 \dagger$ & $\begin{array}{l}0.75 \\
0.71 \\
0.54 \\
0.66\end{array}$ & $\begin{array}{l}36 \cdot 0 \\
34 \cdot 0 \\
25 \cdot 9 \\
31 \cdot 3\end{array}$ & $\begin{array}{l}6 \cdot 0 \\
6 \cdot 2 \\
6 \cdot 4 \\
6 \cdot 0\end{array}$ & $\begin{array}{l}I \cdot 46 \\
I \cdot 56 \\
I \cdot 66 \\
I \cdot 8 I\end{array}$ & $\begin{array}{l}35 \cdot I \\
33 \cdot 7 \\
3 I \cdot 9 \\
23 \cdot 9\end{array}$ & $\begin{array}{l}4 \cdot 0 \\
4 \cdot 0 \\
4 \cdot 0 \\
4.4\end{array}$ \\
\hline L. plantarum & $\begin{array}{r}5.8 \\
17.4 \\
29 \cdot 0 \\
17.4\end{array}$ & $90 \dagger$ & $\begin{array}{l}0.47 \\
0.43 \\
0.37 \\
0.45\end{array}$ & $\begin{array}{l}22 \cdot 5 \\
20 \cdot 7 \\
17 \cdot 8 \\
21 \cdot 6\end{array}$ & $\begin{array}{l}6 \cdot 0 \\
6 \cdot I \\
6 \cdot 2 \\
6 \cdot 0\end{array}$ & $\begin{array}{l}0.63 \\
0.69 \\
0.74 \\
0.82\end{array}$ & $\begin{array}{l}16.4 \\
16.4 \\
16.4 \\
13.5\end{array}$ & $\begin{array}{l}4 \cdot 2 \\
4 \cdot 2 \\
4 \cdot 2 \\
4 \cdot 6\end{array}$ \\
\hline Bact ruminicola & $\begin{array}{r}5.8 \\
17.4 \\
29 \cdot 0 \\
17 \cdot 4\end{array}$ & $90 \dagger$ & $\begin{array}{l}0.94 \\
0.90 \\
0.84 \\
0.76\end{array}$ & $\begin{array}{l}45 \cdot 2 \\
43 \cdot 2 \\
40 \cdot 4 \\
36 \cdot 6\end{array}$ & $\begin{array}{l}5 \cdot 9 \\
6 \cdot 0 \\
6 \cdot 2 \\
6 \cdot 0\end{array}$ & $\begin{array}{l}I \cdot 37 \\
I \cdot 48 \\
I \cdot 52 \\
I \cdot 32\end{array}$ & $\begin{array}{l}40 \cdot 7 \\
38 \cdot 2 \\
36 \cdot 6 \\
28 \cdot 3\end{array}$ & $\begin{array}{l}4 \cdot 4 \\
4 \cdot 4 \\
4 \cdot 5 \\
4 \cdot 8\end{array}$ \\
\hline Bu. fibrosolvens & $\begin{array}{l}17 \cdot 4 \\
17 \cdot 4\end{array}$ & $90 \dagger$ & $\begin{array}{l}0.44 \\
0.89\end{array}$ & $\begin{array}{l}49 \cdot 5 \\
56 \cdot 5\end{array}$ & $\begin{array}{l}6 \cdot I \\
5 \cdot 7\end{array}$ & - & - & - \\
\hline
\end{tabular}

-, Not studied.

* Molar growth yield, calculated from the amount of glucose utilized.

$\uparrow$ Sodium acetate $(50 \mathrm{~mm})+$ propionate $(20 \mathrm{~mm})+$ butyrate $(20 \mathrm{~mm})$.

experiments with media containing $\mathrm{Na}^{+}($as $\mathrm{NaCl}$ ) showed that $S$. bovis was the only bacterium to show a response to changes in $\mathrm{Na}^{+}$concentration, growth being slightly inhibited by $\mathrm{Na}^{+}$in media containing $0.38 \%(\mathrm{w} / \mathrm{v})$ glucose. The results in Table 2 have been corrected for this effect of sodium, which was not shown in media with isosmotic solutions of other electrolytes or $\mathrm{x} \cdot 25 \%$ (w/v) glucose.

The effect of the 90 mM-VFA salt mixture on the rate of growth of $S$. bovis and Bact. ruminicola in media containing $\mathrm{I} \cdot 25 \%(\mathrm{w} / \mathrm{v})$ glucose was determined by measuring the dry weight of cultures at intervals after inoculation. Volatile fatty acid salts had no detectable effect on the growth rate of $S$. bovis during the exponential phase (mean generation time 2I min), the higher cell yield in cultures with VFA salts being the result of an extension of the exponential phase. The difference in molar growth yield of $S$. bovis cultures grown in media with and without the VFA salts mixture was roughly constant from the mid-exponential to the early stationary phase, although in both cases the molar growth yield tended to fall during this period.

The growth rate of Bact. ruminicola was clearly depressed by the presence of the VFA salt mixture. During the exponential phase, Bact. ruminicola grew with a mean generation time of $86 \mathrm{~min}$ in the medium without added VFA salt; with the VFA salt present this increased to I 2 I min.

The effects of phosphate and the 90 mM-VFA salt mixture on the growth of the bacteria in media containing $\mathrm{I} \cdot 25 \%(\mathrm{w} / \mathrm{v})$ glucose were tested under conditions of constant $\mathrm{pH}$ (Table 3). Only Bu. fibrisolvens showed increased growth in VFA-containing media when the $\mathrm{pH}$ was kept constant. Most of the cultures maintained at $\mathrm{pH} 6.3$ grew more rapidly than in previous experiments in which the $\mathrm{pH}$ was allowed to fall, and the nature of the effects was clear after $8 \mathrm{~h}$ incubation. 
Table 3. Dry weight yields of bacteria grown at $\mathrm{pH} 6.3$ in media with $\mathrm{I} \cdot 25 \%(w / v)$ glucose Cultures were incubated for $8 \mathrm{~h}$ at $38^{\circ} \mathrm{C}$.

\begin{tabular}{|c|c|c|c|c|c|}
\hline \multicolumn{2}{|c|}{ Addition (mM) } & \multicolumn{4}{|c|}{ Dry wt $(\mathrm{mg} / \mathrm{ml})$} \\
\hline Phosphate & VFA salts & S. bovis & L. plantarum & Bact. ruminicola & Bu. fibrisolvens \\
\hline $5 \cdot 8$ & & $2 \cdot 58$ & 0.80 & $2 \cdot 37$ & 一 \\
\hline $29 \cdot 0$ & & $2 \cdot 34$ & 0.59 & $\mathrm{I} \cdot 95$ & - \\
\hline $17 \cdot 4$ & & $2 \cdot 54$ & $0 \cdot 70$ & $2 \cdot 16$ & 0.16 \\
\hline $17 \cdot 4$ & $90^{*}$ & $2 \cdot 34$ & 0.66 & $2 \cdot 00$ & 0.29 \\
\hline
\end{tabular}

Neither the concentration of phosphate nor the presence of VFA salts had a marked effect on the proportions of fermentation products of the bacteria. Streptococcus bovis and $L$. plantarum produced between $\mathrm{r} \cdot 80$ and $\mathrm{I} \cdot 92 \mathrm{~mol}$ lactate/mol glucose utilized; acetate and propionate were occasionally found in very small amounts. From each mole of glucose utilized, Bact. ruminicola produced around $\mathrm{I} \cdot 3 \mathrm{~mol}$ lactate, $0.2 \mathrm{~mol}$ succinate and $0.2 \mathrm{~mol}$ acetate. Butyrivibrio fibrisolvens produced about $0.8 \mathrm{~mol}$ formate, $0.35 \mathrm{~mol}$ acetate and $0.6 \mathrm{~mol}$ butyrate/mol glucose. In no case was there evidence of a net uptake of any of the acids by the bacteria.

Veillonella alcalescens and Megasphaera elsdenii were grown in media containing VFA in concentrations similar to those previously described, but with $0.38 \%(\mathrm{w} / \mathrm{v})$ lactate as energy source. The media contained I $7 \cdot 4$ mM-phosphate. In the control medium without VFA, dry weight yields of $0.5 \mathrm{mg} / \mathrm{ml}$ (Megasphaera) and $0.4 \mathrm{mg} / \mathrm{ml}$ (Veillonella) were obtained. In media with the $90 \mathrm{mM}$-VFA mixture, $0.69 \mathrm{mg}$ Megasphaera $/ \mathrm{ml}$, and $0.32 \mathrm{mg}$ Veillonella/ml were obtained. Neither organism reduced the medium $\mathrm{pH}$ markedly, so effects relating to buffer capacity were evidently not involved. The stimulating effect of VFA salts on the growth of Megasphaera was apparently due to the acetate; in fact $50 \mathrm{~mm}$-sodium acetate produced rather greater stimulation of growth than the $90 \mathrm{~mm}-\mathrm{VFA}$ salt mixture, butyrate and propionate being slightly inhibitory. Propionate seemed to account for the major part of the inhibitory effect of the 90 mM-VFA salt mixture on Veillonella.

\section{DISCUSSION}

It has been shown that under certain conditions the dry-weight yield of some rumen bacteria can be increased by the addition of buffer compounds to the medium. The finding that this increase was accompanied by a decrease in the molar growth yield was less predictable and is a point apparently not considered by others (Sargeant, 1968) who have stressed the importance of $\mathrm{pH}$ as a factor limiting the yield of anaerobic fermentations.

The deleterious effects of phosphate on the molar growth yield of $S$. bovis, L. plantarum and Bact. ruminicola tended to be most marked in cultures with a high final $\mathrm{pH}$. This suggests that $\mathrm{HPO}_{4}{ }^{2-}$ may be responsible for much of the inhibitory effect, though the bacteria so far studied are generally thought to take up $\mathrm{H}_{2} \mathrm{PO}_{4}{ }^{-}$rather than $\mathrm{HPO}_{4}{ }^{2-}$ (Mitchell1954). The values for the phosphorus concentration of the bacteria are similar to those of Escherichia coli (Roberts et al. 1955) and are within the range quoted by Hungate (1966) for rumen bacteria.

Unlike phosphate, VFA salts showed the most marked depressions of molar growth yields of $S$. bovis, L. plantarum and Bact. ruminicola in media with excess glucose and low 
final $\mathrm{pH}$. This is consistent with the view that much of the inhibitory activity of VFA is possessed by the undissociated acid (Meynell, I963; Hentges, 1967).

Bacteroides ruminicola appears to be more strongly inhibited by acetate than by the other acids tested, and since acetate is the only one of these acids produced by Bact. ruminicola, it seems possible that much of the effect of acetate may be due to end-product inhibition. The presence of acetate does not markedly alter the proportions of fermentation products of Bact. ruminicola, but presumably slows down the rate of fermentation of glucose, possibly as a consequence of accumulation of pyruvate. Both propionate and butyrate also slightly decrease the molar growth yields of Bact. ruminicola, so other mechanisms must account for their effects, and for the effects of all three VFA salts on the exclusively lactate-producing S. bovis and L. plantarum. Possibly a mechanism is involved similar to that proposed by Sheu \& Freese (1972) and Sheu, Konings \& Freese (1972), who suggested that VFA react with a component of the cell membrane of Bacillus subtilis to inhibit the active transport of important compounds into the cell. End-product effects presumably could explain the inhibitory action of propionate on Veillonella, and of propionate and butyrate on Megasphaera. Stimulation of the growth of Megasphaera (Peptostreptococcus) elsdenii by acetate has previously been reported by Hungate (I966).

The increase in dry-weight yield of $L$. plantarum in media with excess glucose and VFA salts is interesting in view of the studies of Rogosa, Mitchell \& Wiseman (I95I) who developed a medium containing acetate for the selective isolation of Lactobacilli. The present study suggests that $C_{2}$ to $C_{4}$ VFA might generally increase the growth of lactic acid bacteria by increasing the buffer capacity of the medium.

Shane, Gouws \& Kistner (1969) divided their strains of Butyrivibrio into two groups on the basis of fermentation product formation and acetate utilization, and Roche et al. (1973) found that only group 2 isolates were stimulated by VFA, particularly propionate. The present isolate seemed to fit into Group 2 of Shane et al. (I969) in that it did not utilize acetate, produced 'high formate' and 'low lactate', and was stimulated by propionate.

Experiments on the microbiology of gnotobiotic lambs containing a limited rumen flora have shown that when the bacteria studied here were inoculated into lambs fed on various diets, $B u$. fibrosolvens tended to dominate the rumen bacterial flora (Lysons et al. 197I; Mann \& Stewart, 1974). Part of the success may result from the known ability of Bu. fibrisolvens to grown on a wide range of substrates, but it does seem that the favourable response of $\mathrm{Bu}$. fibrisolvens to the presence of VFA is likely to be an important factor in its success, particularly under conditions of energy-limitation.

Other effects found in the experiments with gnotobiotic lambs, particularly the occasional profuse growth of Veillonella, cannot be explained simply in terms of the present results, emphasizing that other factors, not considered here, must play a part in determining the full balance of the bacterial flora of the rumen.

I thank Mr S. O. Mann and Miss C. Grant for the cultures, Mr J. Matheison for glucose analyses, Dr C. Henderson for g.1.c. analysis, Mr I. Skene and Miss E. Parsons for technical assistance and Dr P. N. Hobson for helpful discussion.

\section{REFERENCES}

BArker, S. A. \& Somers, P. J. (I966). A spectrophotometric method for the determination of formic acid in the periodate oxidation of carbohydrates. Carbohydrate Research 3, 220-224.

Bryant, M. P. \& Robinson, I. M. (1962). Some nutritional characteristics of predominant culturable ruminal bacteria. Journal of Bacteriology 84, 605-6I4. 
Clark, B. \& Porteous, J. W. (1964). Determination of succinic acid by an enzymic method. Biochemical Journal 93, 2 IC.

Conway, E. J. (1957). Microdiffusion Analysis and Volumetric Error, 4th revised edn. London: Crosby Lockwood.

Garton, G. A. (195I). Observations on the distribution of inorganic phosphorus, soluble calcium and soluble magnesium in the stomach of the sheep. Journal of Experimental Biology 28, 358-368.

Good, N. E., Winget, G. D., Winter, W., Connolly, T. N., Izawa, S. \& Singh, R. M. M. (I966). Hydrogen ion buffers for biological research. Biochemistry $5,467-477$.

HentGes, D. J. (1967). Influence of pH on the inhibitory activity of formic and acetic acids for Shigella. Journal of Bacteriology 93, 2029-2030.

Hobson, P. N. (1965a). Continuous culture of rumen bacteria: apparatus. Journal of General Microbiology $38, \mathrm{I} 6 \mathrm{I}-\mathrm{I} 66$.

Hobson, P. N. (1965b). Continuous culture of some anaerobic and facultatively anaerobic rumen bacteria. Journal of General Microbiology $38,167-180$.

Hobson, P. N. (1969). Rumen bacteria. In Methods in Microbiology, vol. 3 B, pp. 133-I49. Edited by J. R. Norris and D. W. Ribbons. London and New York: Academic Press.

Hobson, P. N., MANN, S. O. \& Sмiтh, W. (1963). Growth factors for Selenomonas ruminantium. Nature, London $198,213$.

Hungate, R. E. (1950). The anaerobic mesophilic cellulolytic bacteria. Bacteriological Reviews I4, I-49.

Hungate, R. E. (1966). The Rumen and its Microbes. New York and London: Academic Press.

Kempe, L. L., Halvorson, H. O. \& Piret, E. L. (1950). Effect of continuously controlled pH on lactic acid fermentation. Industrial and Engineering Chemistry 42, I852-I 857.

Lysons, R. J., Alexander, T. J. L., Hobson, P. N., ManN, S. O. \& Stewart, C. S. (I97I). Establishment of a limited rumen microflora in gnotobiotic lambs. Research in Veterinary Science 12, 486-487.

Mann, S. O. \& Stewart, C. S. (1974). Establishment of a limited rumen flora in gnotobiotic lambs fed a roughage diet. Journal of General Microbiology 84, 379-382.

Meynell, G. G. (I963). Antibacterial mechanisms of the mouse gut. II. The role of EH and volatile fatty acids in the normal gut. British Journal of Experimental Pathology 44, 209-2 19.

Mitchell, P. (1954). Transport of phosphate across the osmotic barrier of Micrococcus pyogenes: specificity and kinetics. Journal of General Microbiology II, 73-82.

Morley, G., Dawson, A. \& Marks, V. (1968). Manual and autoanalyser methods for measuring blood glucose using Guiacum and glucose oxidase. Proceedings of the Association of Clinical Biochemists 5, 42-45.

Roach, A. G. (1966). Application of Technicon Auto Analyser Equipment to the Routine Determination of Calcium and Phosphorus in Animal Feedstuffs. Automation in Analytical Chemistry. Technicon Symposia I965, pp. I37-I4I. New York: Mediad.

Roberts, R. B., Abelson, P. H., Cowie, D. B., Bolton, E. T. \& Britten, R. J. (1955). Studies of Biosynthesis in Escherichia coli. Carnegie Institution of Washington Publication 607, Washington D.C.

Roche, C., Albertyn, H., van Gylswyk, N. O. \& Kistner, A. (I973). The growth response of cellulolytic acetate-utilizing and acetate-producing Butyrivibrios to volatile fatty acids and other nutrients. Journal of General Microbiology 78, 253-260.

Rogosa, M., Mitchell, J. A. \& Wiseman, R. F. (195I). A selective medium for the isolation and enumeration of oral lactobacilli. Journal of Dental Research 30, 682-689.

SARGEANT, K. (1968). Improvement of yields in anaerobic cultures. Chemistry and Industry, 85-88.

Shane, B. S., Gouws, L. \& Kistner, A. (1969). Cellulolytic bacteria occurring in the rumen of sheep conditioned to low-protein teff hay. Journal of General Microbiology 55, 445-457.

SHeu, C. W. \& FreEse, E. (1972). Effects of fatty acids on growth and envelope proteins of Bacillus subtilis. Journal of Bacteriology III, 5I6-524.

Sheu, C. W., Konings, W. N. \& Freese, E. (1972). Effects of acetate and other short chain fatty acids on sugars and amino acid uptake of Bacillus subtilis. Journal of Bacteriology 111, 525-530.

STEWART, C. S. (1972). Buffer capacity of nutrient media in relation to that of rumen fluid. Biochemical Journal r27, 68P.

Turner, A. W. \& Hodgetts, V. E. (1955). Buffer systems in the rumen of the sheep. II. Buffering properties in relation to composition. Australian Journal of Agricultural Research 6, 1 25-144.

Whitelaw, F. G., HyldgaARd-Jensen, J., Reid, R. S. \& KAy, M. G. (1970). Volatile fatty acid production in the rumen of cattle given an all concentrate diet. British Journal of Nutrition 24, 179-195. 